\title{
Study of The Omnibus Law Method to Create Responsive Laws in Indonesia
}

\author{
Bayu Dwi Anggono ${ }^{1}$, Fahmi Ramadhan Firdaus ${ }^{2}$ \\ \{bayu_fhunej@yahoo.co.id ${ }^{1}$,fhmiramadhan@gmail.com $\left.{ }^{2}\right\}$ \\ ${ }^{1}$ Faculty of Law - University of Jember, Indonesia \\ ${ }^{2}$ Faculty of Law - University of Indonesia, Indonesia
}

\begin{abstract}
Laws and regulations are an important element in formal legal countries (rechtstaat) including Indonesia. In addition, to become the base and limitation for the authorities to act, laws and regulations are also become an instrument to solve the nation and state problems. However, Indonesia's laws and regulations that aim to ensure legal certainty causes legal uncertainty itself. This case is happened because of overlapping law and there are still multi-interpretation rules. The issues discussed in this article are about how the omnibus law method can create responsive laws in realizing justice, utilities and legal certainty in Indonesia. The method used in this article is the conceptual approach and comparative approach. The implementation of the omnibus law in Indonesia must be based on Law No. 12 of 2011 concerning the Formation of Legislation. Finally, in order to create a responsive law, the formation process must involve participation and accommodate the aspirations of the public which is then manifested it into the law and regulations, so that the laws created are appropriate with the public legal needs.
\end{abstract}

Keywords: Omnibus Law, Laws and Regulations, Responsive

\section{Introduction}

As a newly independent country for 75 years, there have been many ups and downs on Indonesia constitutional experienced. History records that we once lived under the authoritarian new order regime of President Soeharto. During the new order regime, the power of law-making which was centered on the President caused the substance of the law to be arranged in the interests of and protecting the President. While the authority of the house of representative only has limitations to approve or reject the bill proposed by the president. The right of house of representative members to submit a bill is complicated by the many requirements in the code of conduct. Therefore, it cannot be denied if many laws were born because of the political will of the President (executive) only.[1]

Until its peak in 1998 the public was in turmoil because the authoritarian leadership of President Soeharto made a multidimensional crisis that stopped him. The transition period from the new order era to the reform era is one of the important events in the journey of the Indonesian nation, one of the demands for reform is the amendment to the Indonesian Constitution 1945 which is considered to be a tool for the new order to perpetuate executive heavy authoritarian rule. Amendment to the constitution change the constitutional order both institutionally and in authority. 
One of the articles in the 1945 Constitution which is considered crucial and urgent to be amended is Article 5 paragraph (1) of the 1945 Constitution which states that the President has the power to make laws, which should be a function of the House of Representatives as a branch of legislative power if seen from pure presidential system. The article was amended through Amendment to Phase I of the 1945 Constitution which was stipulated in the General Session (SU) of the MPR-RI in October 1999 to "The President has the right to submit a bill to the House of Representatives". These provisions cause the transfer of power to form laws, which were previously in executive power divided equally with legislative power.[2]

The checks and balances mechanism in the process of forming laws in the reform era is actually an antithesis of the new order mechanism which produces many repressive law. Mechanisms in the reform era are more directed towards the formation of responsive law, which are adjusted to the public legal needs. One of the responsive law requirements is public participation, this has been formally regulated in Article 96 of Law No. 12 of 2011 concerning Formation of Regulations and Regulations.

Legislative problems then emerge, many laws are not really needed by the community, the quality of the product is inadequate, there are still many laws that conflict with each other, are not well integrated from the start, and laws regarding the public interest are often cause problems. [3] Another crucial issue, namely hyper regulation, needs to know the current number of regulations reaching 42,996. The details are 8.414 central regulations, 14,453 ministerial regulations, 4,164 non-ministerial government institutions and 15,965 regional regulations.[4]

Responds to hyper regulation problem whose effects are like snowballs. In the inauguration speech of President Joko Widodo during his second period of government, the president introduced Omnibus Law as an effort to overcome hyper regulation. The bill drafted using the Omnibus Law method is the Cipta Lapangan Kerja Bill which is now the Cipta Kerja Bill and the Pemberdayaan UMKM Bill. Each of these bills will become an Omnibus Law, a law that also revises several laws, even dozens of laws, aimed at increasing investment and opening up many new jobs.[5]

Omnibus Law is actually widely applied in countries with a common law system, whereas Indonesia itself adheres to civil law. But this is not really a problem, the real challenge is how the laws created through the Omnibus Law method create laws that are responsive and beneficial to society. Considering that the law using the Omnibus Law method regulates various fields so that it has the potential to create conflicting interests of many parties.

\section{Method}

The method used in this article is the conceptual approach, based on how the law is ideally able to realize the goals of the state and protect each citizen, but in reality so many overlapping legal rules actually lead to multiple interpretations and harm citizens. Besides, this article uses a comparative approach method, by comparing and studying the best practices of the omnibus law method in several countries. Seeing its application in various countries, the actualization omnibus law can be a model of formation to resolve overlapping legislation. 


\section{Discussions}

\subsection{Hyper regulation problem in Indonesia}

Hyper and overlapping regulations will result in delays in accelerating development and improving public services because of the long bureaucracy created by regulations. The formation of these regulations was out of control ranging from laws (UU), government regulations (PP), government regulations in lieu of laws (Perpu), presidential regulations (Perpres), to ministerial regulations (Permen). During President Joko Widodo's government from 2014 to October 2018 alone, 8,945 regulations were issued. In detail, there are 107 laws; 452 Government Regulations; 765 Presidential Regulation; and 7,621 Ministerial Regulations.[6]

Not only occurs at the central level, regional levels also experience such conditions. Even the Ministry of Home Affairs in 2016 at that time, canceled 3,143 Regional Regulations (Perda) which were considered problematic. [7] However, the Ministry of Home Affairs' authority was later reviewed in the Constitutional Court. The decision also stated that the authority to revoke the Regional Regulation fully became the authority of the Supreme Court through the Judicial Review.

The beginning of the hyper regulation problem starts from the statutory regulations whose types and hierarchy are under the Law regulated in Article 7 Paragraph (1) of Law No. 12 of 2011 concerning Formation of Legislation, namely government regulations (PP), presidential regulations (Perpres) and regional regulations (Perda).

Affirmed in Article 12 and Article 13 of Law No. 12 of 2011, the substance of government regulations (PP) is to implement the laws as it should. As for the presidential regulations, the substance is what is ordered by law, the material for implementing government regulations, or the material for carrying out governmental powers. So we can conclude that government regulations and presidential regulations take a big role in governance. Even constitutionally in Article 5 Paragraph (1) of the 1945 Constitution, as the highest executive power holder, the president has the authority to determine government regulations to implement the law accordingly.

In addition, laws and regulations that are outside the hierarchy, one of which is ministerial regulation, is also a factor causing hyper regulation. As a product whose existence is recognized and has binding power, hyper regulation is caused by an increase in the number of ministerial regulations not only because their formation is ordered by higher regulations, but also because of the authority held by ministers and / or ministries. Because of the quite extensive power in forming regulations, it is not impossible that the material contained in ministerial regulations can deviate because it ignores the principle of forming legislation. In the end, legal certainty in the administration of government is increasingly difficult to obtain. One of the causes of the emergence of legal uncertainty is that the formation of ministerial regulations does not go through a harmonization process as is the case for the formation of government regulations and presidential regulations. Therefore, both vertically and horizontally, substantively, ministerial regulations are very likely to present regulations that are not harmonious and out of sync with the type and hierarchy of other statutory regulations, including conflicting with the law. [8]

Disharmonization or overlap between legislation both vertically and horizontally which causes legal uncertainty makes investors think many times to invest in Indonesia. In connection with the large number of state institutions that have the authority to form laws and regulations, it is not uncommon for disharmony and incompatibility between one legal norm and another. 
Therefore state institutions that have the authority to form laws and regulations also have an obligation to harmonize.

Law harmonization is a scientific activity towards the process of harmonizing written law based on philosophical, sociological, economic and juridical values. In its implementation, the harmonization activity is a comprehensive study of a draft legislation with the aim of finding out whether the draft regulation in various aspects reflects harmony or conformity with other national legislation, with unwritten laws that live in society, or with international conventions and agreements, both bilateral and multi-lateral that have been ratified by the Government.[9]

From 2017-2019 (as of september 2019) there are 4,838 ministerial / head of nonministerial government agencies with the following details:

Table 1. Number of ministerial regulations since 2017-2019 (as of September 2019)

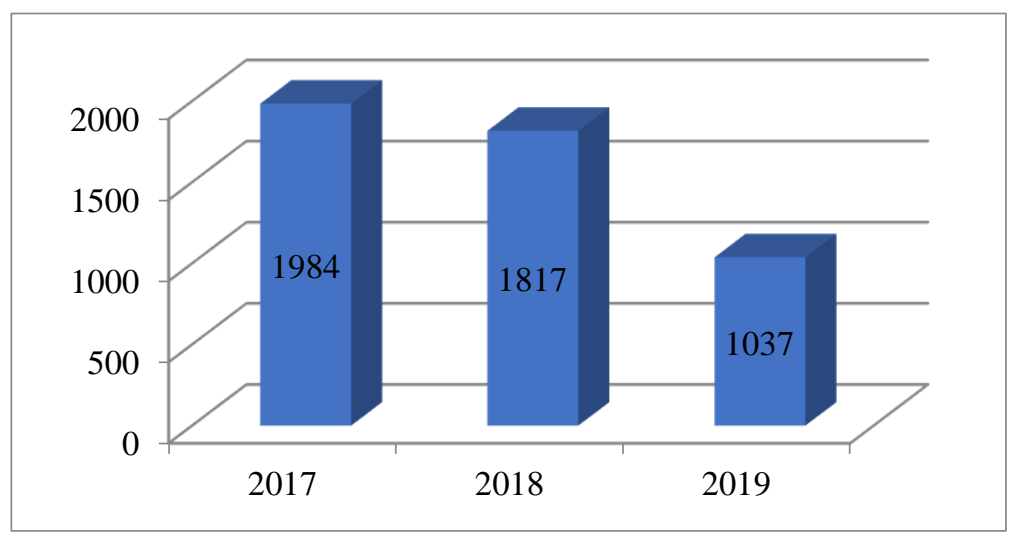

Source: Directorat General of Legislation Ministry of Law and Human Rights, 2019

Sectoral ego between ministries and / or institutions and then regional autonomy which gives local government authority to make regional regulations is the main cause of hyper regulation because of the harmonization of laws and regulations. To break the disharmony chain, in fact the government through the Ministry of Law and Human Rights has issued Minister of Law and Human Rights Regulation No. 22 of 2018 concerning Harmonization of Draft Laws and Regulations Formed in the Regions by the Drafters of Laws and Regulations of the Minister of Law and Human Rights No. 23 of 2018 concerning Harmonization of Ministerial Draft Regulation, Draft Regulation of Non-Ministerial Government Institutions, or Draft Regulation of Non-Structural Institutions by Drafting Legislation, besides that the house of representatives and the government revised Law No. 12 of 2011 as amended by Law No. 15 of 2019 concerning Formation of Legislation as a serious effort to overcome the regulatory problem. 


\subsection{Omnibus law method as a solution}

To reorganize regulations that were much, President Jokowi chose to use the Omnibus Law method, based on the Oxford Dictionary of English, the word "omnibus" means "a volume containing several books previously published separately". Literally, "omnibus" comes from the Latin "omnis" which means "every" or "all", or rather "all, every, the whole, of every kind". In the Black's Law Dictionary 10th, the term "omnibus bill" is interpreted as follows:

1) a single bill containing various distinct matters, usu. drafted in this way to force the executive either to accept all the unrelated minor provisions or veto the major provision;

2) bill that deals with all proposals relating to a particular subject, such as an "omnibus judgeship bill" covering all proposals for new judgeships or an "omnibus crime bill" dealing with different subject such as new crimes and grants to states for crime control.

Maria Farida Indrati defines the omnibus law as a (new) law containing or regulating various substances and various subjects for the simplification of various applicable laws. It is not appropriate if the omnibus law is equated with the umbrella law (raamwet, basiswet, moederwet), which is the law which is the core of other laws so that its position is higher than the sub-core law because this umbrella law bestows various further arrangements by delegation to other laws.[10]

Generally, the Omnibus Law is a new law that contains or regulates a variety of materials and subjects that aim to simplify various laws that still apply. The Omnibus Law method in forming legislation is mostly adopted by countries that adhere to the Anglo-Saxon or Common Law traditions, such as the United States of America, Canada and Ireland which in 2008 issued a law that repealed 3,225 laws.

In Canada, there is one phenomenal omnibus law, the 120-page Criminal Law Amendment Act, which was approved in the period 1968-1969. The omnibus law was passed during the leadership of the Minister of Justice Pierre Trudeau, he considered the law to be "the most important reform in the applied criminal law". These rules legalize homosexuality, abortion, lottery, restrictions on possession of weapons, to regulate driving rules. Gunter considered that the government at that time was trying to minimize the negative impacts that must be borne. [11]

The omnibus law method is most likely to be successfully implemented if it is guided by the concept of single subject clause (the law of one theme). [12] As a reference, we can see in the constitution of one of the states of the United States of America, Minnesota, in Article 4 Section 17 of the Constitution of the State of Minnesota emphasizes:

Laws to embrace only one subject. No law shall embrace more than one subject, which shall be expressed in its title.

As with Minnesota, the state of California even limits the use of Omnibus Law. The Constitution of the State of California in Article 4 Section 24, emphasizes:

Every Act shall embrace but one subject, which subject shall be expressed in its title. But if any subject shall be embraced in an Act which shall not be expressed in its title, such Act shall be void only as to so much there of as shall not be expressed in its title...."

Indonesia needs to learn from the application of omnibus law in these countries, because the Omnibus Law used in the Cipta Kerja Bill is not a single subject clause, Substantially there are 11 different clusters of subjects that have an impact on 82 Laws and 1,201 articles. The 11 clusters of the Cipta Kerja Bill include:

1) Simplification of land licensing

2) Investment requirements

3) Employment 
4) Ease and protection of MSMEs

5) Ease of business

6) Research and investment support

7) Government administration

8) Imposition of sanctions

9) Control of land

10) Ease of government projects

11) Special Economic Zones

The first challenge that must be anticipated in the formation of the Omnibus Law is that, with enough clusters, it will be difficult and less effective if the Omnibus Law is submitted to several ministries. A single institution is needed to formulate the omnibus law bearing in mind that the omnibus law is a law that contains substance or material to negate previous legal norms that are spread in several laws, needing careful preparation by ruling out sectoral egos. [13]

The formation of the institution has even been mandated by Law No. 15 of 2019 concerning revision to Law No. 12 of 2011 concerning the Formation of Laws and Regulations, Article 99A affirms:

"Pada saat pembentukan kementerian atau lembaga yang menyelenggarakan urusan pemerintahan di bidang Pembentukan Peraturan Perundang-undangan belum terbentuk, tugas dan fungsi Pembentukan Peraturan Perundang-undangan tetap dilaksanakan oleh menteri yang menyelenggarakan urusan pemerintahan di bidang hukum."

This institution will also later review and tidy up all the technical rules that are formed to implement the Cipta Kerja Bill, because automatically there will be a lot of technical regulations that must be synchronized in the form of ministerial regulations, ministerial decrees, and so on. Because it would be futile to use Omnibus Law if the implementing regulations are not implemented, this will actually aggravate Hyper Regulation.

The second challenge, legally the Omnibus Law method is not legally clear, in Law No. 12 of 2011 neither the article nor the appendix regulate the method. If the government and the House of Representatives impose it, then this will set a bad precedent because both of them violate the provisions they made themselves. So the solution is to first revise the law and then include rules regarding the Omnibus Law method.

The third challenge, according to US journalist Lorne Gunter, is that the Omnibus Law is anti-democracy because in its process of limiting debate and control over its application, in the past Omnibus Law has often been used to pass controversial rules. [14] So it can be said that Omnibus Law is likely to produce repressive legal products that are misused to benefit certain interest groups and cause harm to the community. An example of the controversial Omnibus Law is Prime Minister Trudeau's Bill C-94, the 1982 Energy Security Act, which angered the Conservative Progressive opposition.[15]

This must be avoided by Indonesia because we must learn from the new order, in a modern democratic country now, the laws needed are responsive characters that provide benefits and meet the legal needs of society. The process of establishing laws that use the Omnibus Law method must be participatory in order to produce responsive laws. Regarding responsive law concept will be discussed in the next section. 


\subsection{Responsive law concept}

Philippe Nonet and Philip Selznick divide the three character of the law applied in society. First, the law as servants of repressive power (repressive law). Second, the law as a separate institution capable of taming repression and protecting its integrity (autonomous law). Third, law as a facilitator of various responses to social needs and aspirations (responsive law). In this section the author only discusses the character of responsive law, but to make it easier to understand the differences between the three legal characters can be seen in the following table:

Table 2. The three characteristics of law

\begin{tabular}{|c|c|c|c|}
\hline & Repressive Law & Autonomous Law & Responsive Law \\
\hline Purpose & Order & Legitimacy & Competence \\
\hline Legitimacy & $\begin{array}{l}\text { Social security and } \\
\text { nation goals (raison } \\
\text { d'etat) }\end{array}$ & Procedural justice & Substantial justice \\
\hline Regulation & $\begin{array}{l}\text { hard and detailed but } \\
\text { weak against } \\
\text { lawmakers }\end{array}$ & $\begin{array}{l}\text { Extensive and } \\
\text { detailed; binding } \\
\text { both the law maker } \\
\text { and the ruled }\end{array}$ & $\begin{array}{l}\text { Subordinate to } \\
\text { principles and } \\
\text { policies }\end{array}$ \\
\hline Consideration & $\begin{array}{l}\text { Ad hoc: makes it } \\
\text { easy to achieve goals } \\
\text { and is particular }\end{array}$ & $\begin{array}{l}\text { Very attached to } \\
\text { legal authority; } \\
\text { vulnerable to } \\
\text { formalism and } \\
\text { legalism }\end{array}$ & $\begin{array}{l}\text { Purposive (goal } \\
\text { oriented); expansion } \\
\text { of cognitive } \\
\text { competence }\end{array}$ \\
\hline Discretion & $\begin{array}{l}\text { Very wide; } \\
\text { opportunistic }\end{array}$ & $\begin{array}{l}\text { Limited by } \\
\text { regulations; narrow } \\
\text { delegation }\end{array}$ & $\begin{array}{l}\text { Wide, but still in } \\
\text { accordance with the } \\
\text { objectives }\end{array}$ \\
\hline Coercion & $\begin{array}{l}\text { Extensive; weakly } \\
\text { restricted }\end{array}$ & $\begin{array}{l}\text { Controlled by legal } \\
\text { restrictions }\end{array}$ & $\begin{array}{l}\text { Positive search for } \\
\text { alternatives, such as } \\
\text { intensive, self- } \\
\text { sustaining liability } \\
\text { systems }\end{array}$ \\
\hline Morality & $\begin{array}{l}\text { Communal morality; } \\
\text { legal moralism; } \\
\text { "Morality limitation" }\end{array}$ & $\begin{array}{l}\text { Institutional } \\
\text { morality; that is, } \\
\text { filled with the } \\
\text { integrity of the legal } \\
\text { process }\end{array}$ & $\begin{array}{l}\text { Civil morality; } \\
\text { "cooperation" }\end{array}$ \\
\hline Politic & $\begin{array}{l}\text { Law is subordinate } \\
\text { to power politics }\end{array}$ & $\begin{array}{l}\text { "Independent" law } \\
\text { is separate from } \\
\text { politics }\end{array}$ & $\begin{array}{l}\text { Integrated legal and } \\
\text { political aspirations; } \\
\text { power integration }\end{array}$ \\
\hline
\end{tabular}




\begin{tabular}{|l|l|l|l|}
\hline Hope for Obedience & $\begin{array}{l}\text { Unconditional; } \\
\text { disobedience is } \\
\text { punished as } \\
\text { insubordination }\end{array}$ & $\begin{array}{l}\text { Deviations of } \\
\text { justified regulations, } \\
\text { for example to test } \\
\text { the validity of laws } \\
\text { or orders }\end{array}$ & $\begin{array}{l}\text { Disobedience is seen } \\
\text { from the aspect of } \\
\text { substantive danger; } \\
\text { seen as a lawsuit } \\
\text { against legitimacy }\end{array}$ \\
\hline
\end{tabular}

Source: Philippe Nonet and Philip Selznick, Law and Society in Transition : Toward Responsive Law, 1978.

According to the Indonesian Dictionary, the law is the laws, regulations, and so on to regulate social life, [16] and responsive means fast (like) respond; responsive. [17] responsive law according to Philippe Nonet and Philip Selznick in their book "Law and Society in Transition towards Responsive Law". Responsive law is a critique of legal theory that emphasizes the formality side and overrides reality (repressive law and autonomous law), the ideal law must be competent and also fair, it should be able to recognize the public desires and be committed to achieving substantive justice rather than procedural. [18]

It can be concluded that responsive law is a legal character that receives as much legal input as possible and then takes a solution which can be a meeting point for the legal interests of the community in general. Responsive law in principle is an accommodative and aspirational law of the desires of the people who will be governed.

Related to the application of the Omnibus Law in Indonesia, this is a challenge that must be resolved together, many cross-sectoral arrangements will certainly have the potential for a conflict of interests involved in the formation of the Omnibus Law, House of Representatives and the Government must not only submit to political interests, both must absorb aspirations and open space for public participation in forming laws. So that the Omnibus Law produced has responsive legal characteristics that are a solution to meet the legal needs of the wider community. Maria Farida Indrati provided several points of recommendations that must be considered so that the Omnibus Law law can bring justice, expediency and legal certainty. First, the fulfillment of the principles of openness, prudence, and public participation. Second, broad socialization is needed, especially for officials and parties involved in the substance of the bill, legal practitioners, and academics; Third, the discussion process in the House of Representatives must be transparent with regard to input from parties related to the bill, and not to rush into the discussion; Fourth, consider the effective period of enactment of the Omnibus Law; and Fifth, consider the applicability of existing affected laws.[19] 


\section{Conclusion}

Regulatory reform was a priority during the second period of President Joko Widodo's government, he chose to form an Omnibus Law to revise several laws as well as a way to organize regulatory problems, but many issues must be considered in implementing the Omnibus Law because this method is pragmatic, less democratic and limit the space for participation, this can be seen from other countries that have applied before. Because the Omnibus Law method has not yet been regulated in Law No. 12 of 2011 concerning the Formation of Regulations and Regulations, the law should first be revised to include the Omnibus Law mechanism. Further notes, it is feared that it would not be effective if the Omnibus Law was formed if submitted to several ministries. A single, specialized institution that handles regulation is needed because it requires carefulness, prudence and minimizing the sectoral ego in its formation. It is expected that each law product specifically formed through the Omnibus method will always be open to public participation and receive their aspirations, so that the resulting law is responsive in character to meet the legal needs of each community, not only the authorities or certain interest groups.

\section{References}

[1] H. Moh. Alifuddin, Berdemokrasi: Panduan Praktis Perilaku Demokratis. Jakarta: Magna Script Publishing, 2012. hal. 102

[2] Pataniari Siahaan, Politik Hukum Pembentukan Undang - Undang Pasca Amandemen UUD 1945. Jakarta: Konstitusi Press, 2012. hal. 284

[3] Bayu Dwi Anggono, Perkembangan Pembentukan Undang-Undang di Indonesia. Jakarta: Konstitusi Press, 2014. hal. 10-11.

[4] Gaudensius Suhardi, “Obesitas Regulasi” Media Indonesia. [Online]. Available: https://mediaindonesia.com/podiums/detail_podiums/1671-obesitas-regulasi

[5] JEO News, "Naskah Lengkap Pidato Presiden Joko Widodo dalam Pelantikan Periode 2019-

2024" Kompas. [Online]. Available: https://jeo.kompas.com/naskah-lengkap-pidato-presiden-jokowidodo-dalam-pelantikan-periode-2019-2024

[6] Agus Sahbani, "PSHK: Pemerintahan 2019-2024 Harusnya Fokus pada Pembenahan Regulasi" Hukum Online. [Online]. Available:

https://www.hukumonline.com/berita/baca/lt5d2ee5ac2bb87/pshk--pemerintahan-2019-2024harusnya-fokus-pada-pembenahan-regulasi/

[7] Moh. Nadlir, “Ada 62.000 Aturan, Indonesia Dianggap "Obesitas Regulasi"” Kompas. [Online]. Available: https://nasional.kompas.com/read/2017/11/10/19062511/ada-62000-aturan-indonesiadianggap-obesitas-regulasi?page =all

[8] Saldi Isra, "Merampingkan Regulasi" saldiisra.web.id. [Online]. Available: https://www.saldiisra.web.id/index.php/tulisan/artikel-koran/11-artikelkompas/630-merampingkanregulasi.html

[9] Ahmand M. Ramli, Koordinasi dan Harmonisasi Peraturan Perundang-undangan, Jakarta, Majalah Hukum Nasional Departemen Hukum dan Hak Asasi Manusia, 2008. hal. 4.

[10] Maria Farida Indrati, ““Omnibus Law”, UU Sapu Jagat?”, Harian Kompas, 4 Januari 2020, hal. 6

[11] Lorne Gunter, "Omnibus bills in Hill history" Toronto Sun [Online]. Available: https://torontosun.com/2012/06/18/omnibus-bills-in-hill-history/wcm/5b85232b-b8b4-4c9b-b5b7$9480 \mathrm{~b} 9821292$ 
[12] Feri Amsari, "Salah Kaprah Omnibus Law" Tempo [Online]. Available: https://kolom.tempo.co/read/1316101/salah-kaprah-omnibus-law

[13] Antara, "Janji Presiden Bentuk Pusat Legislasi Nasional Ditagih" Media Indonesia [Online]. Available: https://mediaindonesia.com/read/detail/267464-janji-presiden-bentuk-pusatlegislasi-nasional-ditagih

[14] Lorne Gunter, Op. Cit.

[15] Louis Massicote, Canadian Parliamentary Review. Spring: Vol 36 no 1, 2013. hal. 13

[16] Departemen Pendidikan Nasional, Kamus Besar Hukum Indonesia Edisi keempat. Jakarta: Gramedia Pustaka Utama, 2008. hal. 510

[17] Ibid. hal. 1170

[18] Philippe Nonet and Philip Selznick, Hukum Responsif Pilihan di Masa Transisi. Jakarta: Ford Foundation/Human Rights, 2003. hal. 60

[19] Maria Farida Indrati, "Menyikapi Omnibus Law Sebagai UU Sapu Jagad”, Bahan paparan dalam Seminar: "Menyikapi Omnibus Law: Pro Kontra RUU Cipta Lapangan Kerja"

diselenggarakan oleh Djokosoetono Research Center dan Bidang Studi Hukum Administrasi Negara Fakultas Hukum Universitas Indonesia. Depok, 6 Februari 2020 